\title{
How and Why "Bobos" Became French
}

\section{Scott Gunther}

["How and Why 'Bobos' Became French," French Politics, Culture and Society, winter 2016, Volume 34, Issue 3.]

Do you know what a "bobo" is? If you are French or an American who has spent significant time in France, you probably do, but if you are an American without much experience in France, it is likely that you do not, even though the term was originally created to describe an American phenomenon. The word "bobo" is short for "bohemian bourgeois," a curious combination of two terms that would normally be placed in opposition. It was coined in 2000 by David Brooks in his book Bobos in Paradise: The New Upper Class and How They Got There. ${ }^{1}$ He defines the bobo as a cosmopolitan, upper-middle-class individual who espouses liberal politics (especially with regard to social and environmental issues) and eschews conspicuous consumption, spending large amounts of money instead on discreet luxuries. In a nutshell, as Brooks recently told me in a telephone interview, "the shorthand version is that bobos are people with ' 60 s values and '90s money." In his book he explains that, "when faced with a tension between competing values, [bobos] do what any smart privileged person bursting with cultural capital would do. They find a way to have both. They reconcile opposites." ${ }^{3}$ The book received media attention in the United States when it was first published, but the term bobo never really took hold in the American lexicon, at least not as much as it did in France, where soon after Brooks's book was translated into French, in 2000, the term took off to the point where most people, French and American, have almost entirely forgotten its American origins. 
One measure of the popularity of the term in France and in the United States is the frequency with which it has occurred in the press of the two countries. Figure 1 shows that the term received some attention in the US shortly after the publication of Bobos in Paradise in 2000, but that this attention fell off quickly in the years immediately following. Meanwhile, in France the frequency of the term increased steadily over the period from 2000 to 2013 .

Figure 1. Frequency of the term "bobo" in the French and US presses over time 4

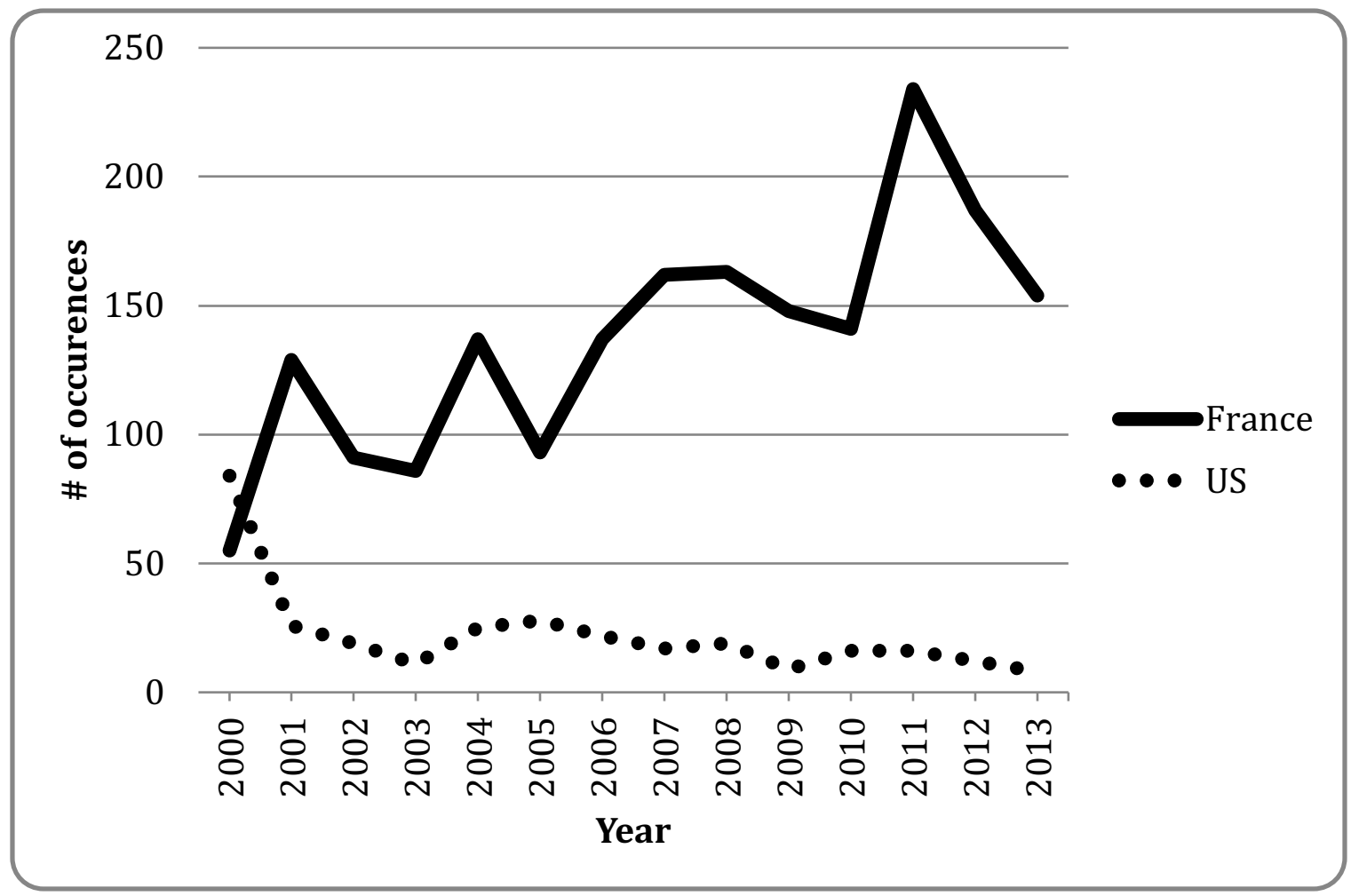

In Figure 1, the frequency of the term in 2000 in France and in the United States appears to be similar. However, it is important to note that during this early usage of the term in France, "bobo" usually referred to an American phenomenon. Figure 2 shows how quickly this changed, such that by 2002, the association of "bobo" with the United States occurred in only a small percentage of articles. 
Figure 2. Percentage of articles in the French press where the term "bobo" is accompanied by a reference to the United States over time ${ }^{5}$

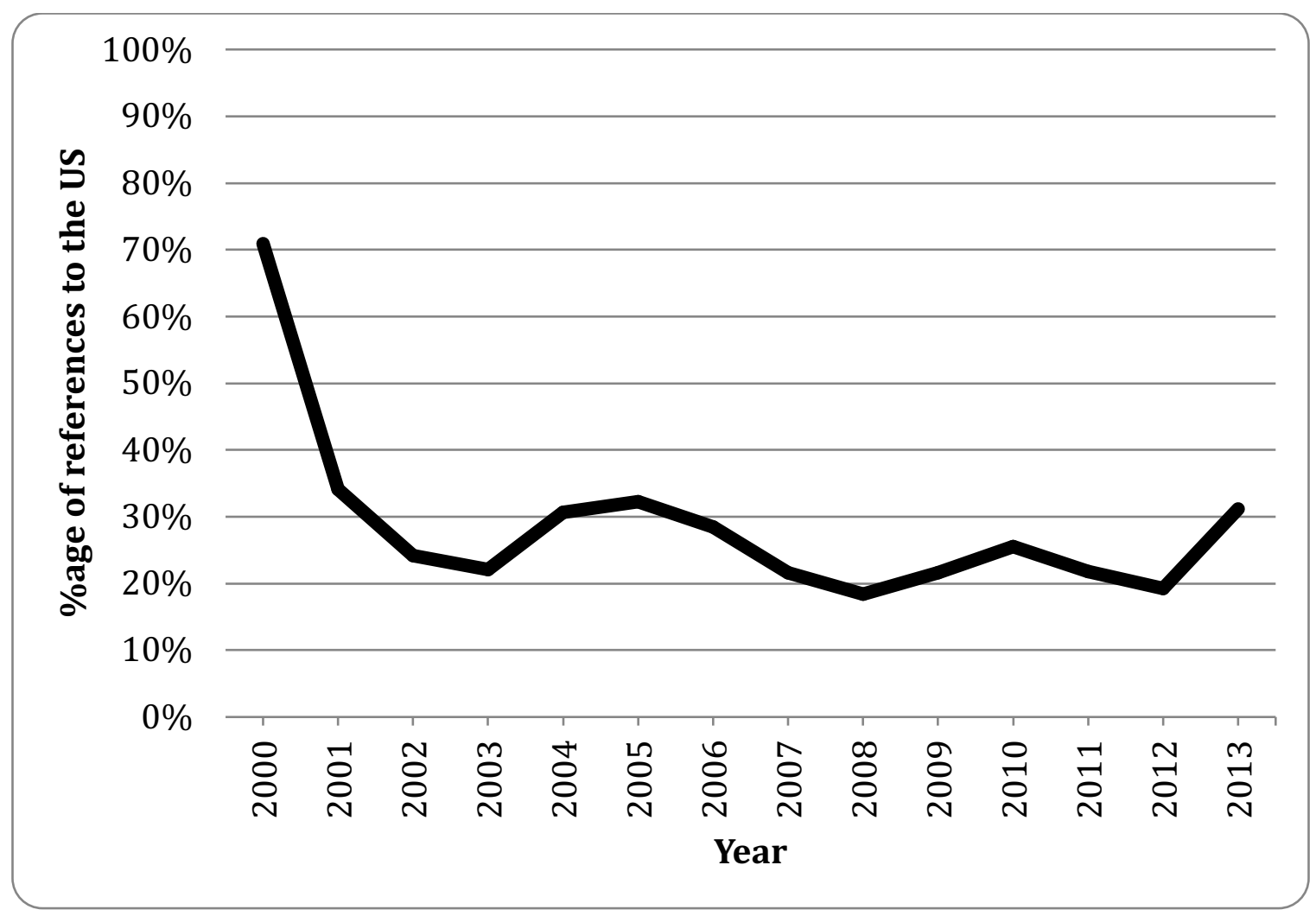

Similarly, in the United States, articles referring to bobos have increasingly associated this social phenomenon with France, as indicated in Figure 3.

Figure 3. Percentage of articles in the US press where the term "bobo" is accompanied by a reference to France over time ${ }^{6}$ 


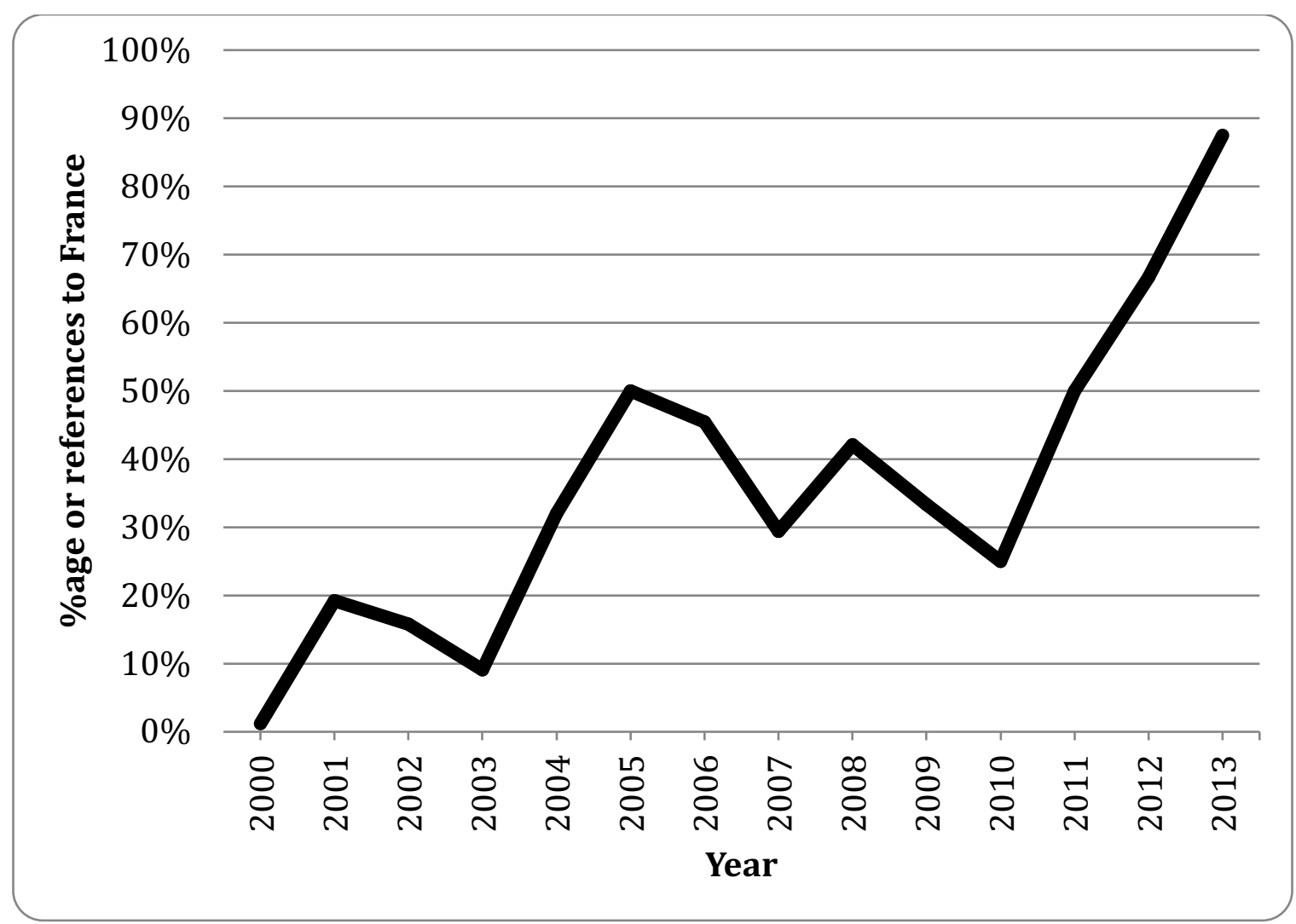

Consequently, not only has the use of the term fallen off in the United States

while it has increased in France, but the concept, which was initially considered an American phenomenon, has also become increasingly thought of as French in the press of both countries. Why is it that the use of this term has become widespread in France and has almost disappeared in the American context? Did something distinctive about the early 2000s in France contribute to its success?

To get a clearer sense of how bobo is being defined in the French context and how one might explain the term's trajectory, in the summers of 2013 and 2014 I conducted twenty-four interviews, each roughly an hour long, with Parisians living in the Ninth, Tenth, Eleventh' Twelfth, Nineteenth, and Twentieth arrondissements (areas to the northeast of the center of Paris) who either self-identified as "bobo" or were fairly certain that others would identify them that way. I found my first nine interviewees by asking 
acquaintances if they knew anyone who would fit either of these descriptions. After that, at the end of each interview, I would ask the interviewees to give me names and contact information for other people, a method commonly referred to as "snowball sampling," which has both disadvantages (the sample may not be representative, as it lacks randomness) and advantages (it allows surveyors to locate members of populations for whom there might not be any lists or other means of finding them). I recorded and transcribed each interview. Of the twenty-four interviewees, ten were men and fourteen were women. The average age was 43.6 years, with ages ranging from 33 to 49 . I use pseudonyms to preserve the anonymity of the interviewees, and the translations from French to English are my own. I should mention that the interviewees knew I was American, which could have influenced the ways in which they spoke to me. They may have provided me, for example, with more contextual information than they would have with a fellow Parisian. After asking for basic demographic information, including age and professional status, I began each interview by asking the person to define "bobo." This part of the discussion was open-ended and took up most of the time. I listened, with occasional interruptions to ask for clarification or elaboration of various elements of their definitions.

The study that resulted from these interviews and from an analysis of French popular media is divided into four sections. I start by looking at popular media representations of bobos in France, which tend to be derogatory, highlighting the supposed hypocrisy of this population. In the second section, I trace the genealogy of the term, first by considering the possibility of precursors to contemporary bobos and then by looking at the context of the early 2000 s, particularly the rapid gentrification of 
northeastern Paris at that time and the ways in which bobos turned living in a socially diverse neighborhood into something desirable, even though their interaction with the original working-class inhabitants remained limited. This further underscores the extent to which bobos are understood to be hypocritical and will help to explain why few people self-identify as such. Next, I outline the ways in which my Parisian interviewees defined "bobo culture" (including political views, family, fashion, professional life, and cultural tastes) in 2013 and 2014. Through these interviews, it became clear that bobos are commonly understood to be more bourgeois than bohemian, and that notions of cultural capital make up a significant component of the interviewees' definitions. In the final section, I argue that the relative prominence of the term in France can be attributed to three factors: that the bourgeois part of the definition is more important than the bohemian part; that the concept of bourgeois is more readily understood in France than in the United States; and especially the inaptness of Bourdieusian notions of cultural capital in the United States as compared to France, given their centrality to the definition of bobo.

\section{Bobos in the French Popular Media}

Since 2000, several books - along with a popular song by the French singer Renaudhave addressed the topic, most offering a pejorative, critical take on the term. Bienvenue $\grave{a}$ Boboland (2008) is a graphic novel that exposes the hypocrisy of a population that seeks to live in ethnically and socio-economically diverse neighborhoods without actually getting too close to any of their inhabitants. ${ }^{7}$ Global Boboland (2009), its sequel, follows many of the same characters on their travels to "exotic" places around the world in a 
desperate but ultimately unsuccessful attempt to experience authenticity. ${ }^{8}$ Bobos de merde (2011) tells the story of Benoit, a Parisian bobo who teaches Bixente, a new arrival in the city, how to be a bobo. It offers a collection of clichés and self-deprecating humor (Benoît and Bixente are the names of the authors, and the book is based on their experience). Bixente sees bobos as individuals "caught between their bourgeois life and their bohemian values, [who] expose their internalized guilt by refusing to admit their condition." In Le Dictionnaire du look (2011), a bobo is defined as "A walking paradox. The bobo manages to reconcile classic tradition with a relaxed lifestyle, a three-day beard with an executive's salary. They raise kids in a apartment with exposed beams, bathed in light and 'lo-fi' music."10 Renaud's song provides an assortment of clichés about where bobos live (in a loft in a trendy neighborhood); their tastes in leisure activities (museums, art galleries, old bistros, Japanese restaurants, Korean cinema, riding bicycles, the cultural television station Arte, the musical group Manu Chao, the magazines Inrockuptibles and Télérama, the authors Michel Houellebecq, Philippe Djian, and Emil Cioran); the products they consume (clothes from Diesel, Armani, Kenzo, or Zadig et Voltaire, food from organic markets); the goals of bobo parents (raising well-behaved and cultured children who have read The Little Prince by age six and who go to private school); and their politics (they vote for environmentalists and adore the former socialist, gay mayor of Paris, Bertrand Delanoë, who is remembered in particular for making the city more bicycle friendly). Renaud ends the song by recognizing that his words might be brutal (assassin), reluctantly admitting that in some respects he might even be a little like the bobos he denigrates. What matters is that in all these representations, the bobo is portrayed in a negative light, as a hypocritical, superficial, urban dweller. One gets the 
sense that a bobo is almost always someone else and understands why people would be generally reluctant to identify themselves as such. ${ }^{11}$

\section{From Twentieth-Century Proto-Bobos to Millennial Gentrifiers}

As a part of each interview, I asked the interviewees if they thought there were any precursors to bobos, and whether the same population might have existed in some form before the arrival of the term. The consensus was that there were people who fit the definition before the category had a name:

“My parents were bobos. They experienced the student revolts of May 1968.

They lived in Provence, both coming from bourgeois families, but with ' 68 they were a little hippie-ish, so they were both bohemian and bourgeois." (Nicole) "There have always been bobos, even before the term was coined. I'd say that the gentrification of the Fourteenth arrondissment [in the south of Paris] in the 1980s was a similar process." 12 (Julien)

"I grew up in a bourgeois family with aspirations of creating new models for living, in what I'd call a 'proto-bobo' family." (Vincent)

I then asked them to compare their definition of bobo with other pre-existing categories. I first asked what differences or similarities they perceived with the term gauche caviar. All of the interviewees were familiar with this term and, generally speaking, saw clear differences between bobos and the gauche caviar, mainly because the latter term refers to a small population of political elites from the socialist party, who have much more economic capital than bobos do, but also because, for many of them, it is strongly linked to the historical context of the years of François Mitterrand's 
presidency. Etienne suggested that bobos could be referred to as the "salmon left, actually no, the organic salmon left." Thomas offered a similar observation: "It's not the caviar left but the fish roe left (gauche tarama)."

All interviewees were also familiar with the term "yuppie." They linked it to a particular period in time (the 1980s or maybe the 1990s) and place (mostly the United States), but, more importantly, they saw this population defined purely in terms of economic capital and thus as essentially different from their understanding of bourgeois, which requires significant cultural capital as well.

I also inquired about the term $b a b a \mathrm{cool}$, and none of them thought it could be applied to bobos, partly because babas cools are more engaged politically, partly because they have less economic capital than bobos. ${ }^{13}$

“The difference between babas cools and bobos is that you don't need money to be a baba cool. Maybe a bobo is a baba chic?" (Anne) "Babas cools are more politically militant than bobos, they have too much interiorized guilt to desire precious or expensive things. They tend to live in the country, they're less fun than bobos. They're less concerned with social distinction.” (Etienne)

"A baba cool is much less attached to the family." (Agathe)

I also asked whether they saw an overlap between the terms bobo and hipster, as some US media sources have equated American hipsters with French bobos. ${ }^{14}$ Only about half of the interviewees had heard the term before, and only a few were able to give a clear definition. For those who did offer one, they said that they imagined hipsters as younger than bobos (early 20 s as opposed to late 30 s through mid 50 s). They also thought 
that hipster referred merely to a style of dress and did not include the political values and cultural commitments of the bobo.

"Hipsters are younger than bobos. Bobos are well established, while hipsters don’t have children.” (Xavier)

At the end of the interview, I asked them all in what year they would estimate they first heard the term bobo, and the average response was 2002 (with answers ranging from 1998 to 2008), which is close to the time when Brooks's book was translated into French and when the French media gave the term increased attention. Four of the interviewees said they strongly associated the arrival of the term with the election of Delanoë as mayor of Paris in 2001. Indeed, a widely cited post-electoral study suggested that Parisians elected their first socialist mayor largely because of the growing population of bobos. ${ }^{15}$

The Early 2000s: A Fertile Terrain for Gentrification

Figure 4. A new organic food store among sex shops: an example of gentrification on the edges of "Boboland," at 43, boulevard de Clichy, Paris 


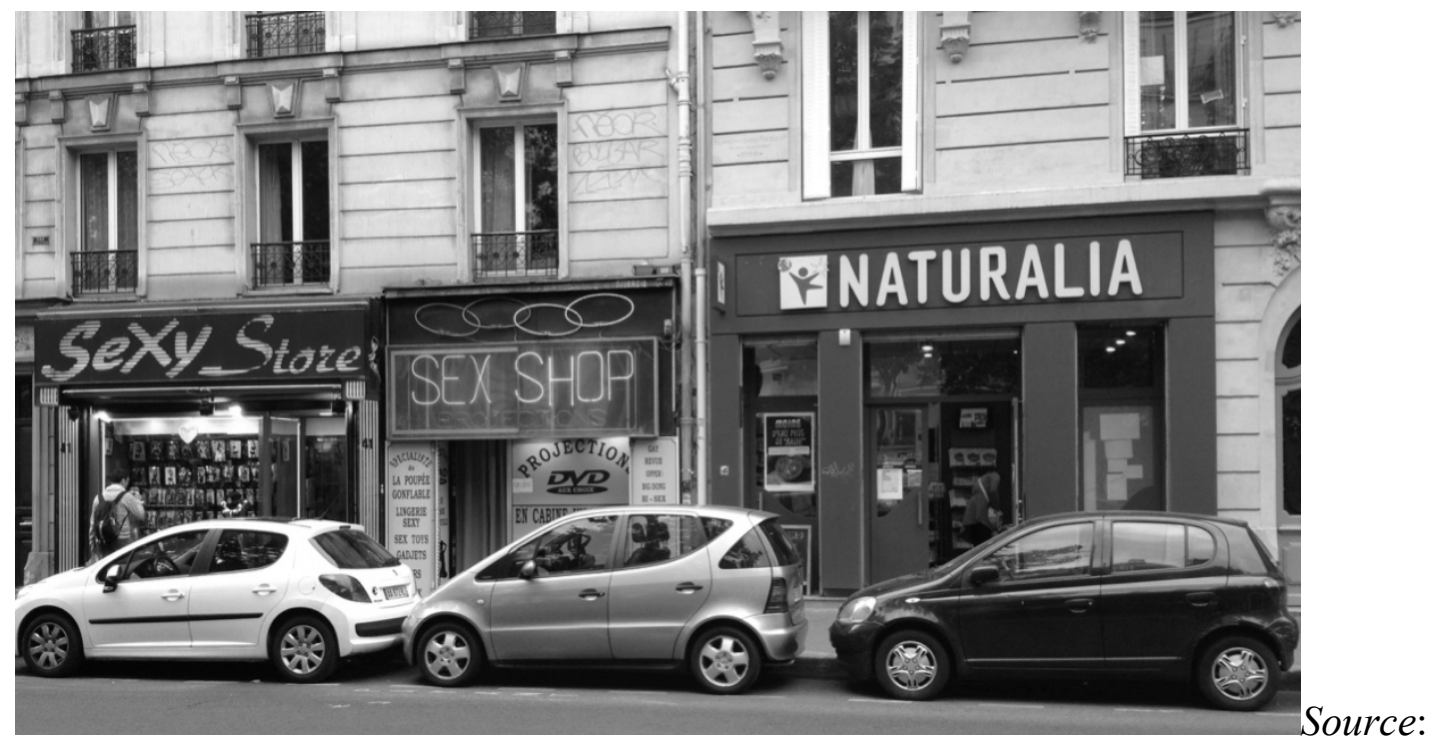

Author's photograph, July 2013.

That the interviewees agreed that some people fit the definition of bobo before the category had a name raises the question of whether there might have been something distinctive about the early 2000s that increased the need for such a label. One answer can be found by examining the effects of the rapid transformation of northeastern Paris at that time.

For every informant in this study, a central component of the definition of bobo was geographic. All interviewees mentioned the areas in which bobos lived, often as the first criterion in their definition. As soon as they mentioned geography, I would interrupt and ask them to draw a map of Paris on a blank sheet of paper indicating the boundaries of "Boboland" to elicit a more precise picture. According to their maps, bobos live in the recently gentrified neighborhoods of northeastern Paris and perhaps in the suburb of Montreuil as well. The summary map below shows how many of the interviewees included each of the Paris arrondissements (along with Montreuil) in their maps. 
Figure 5. Number of interviewees who said bobos live in each of the $\operatorname{arrondissements}^{16}$

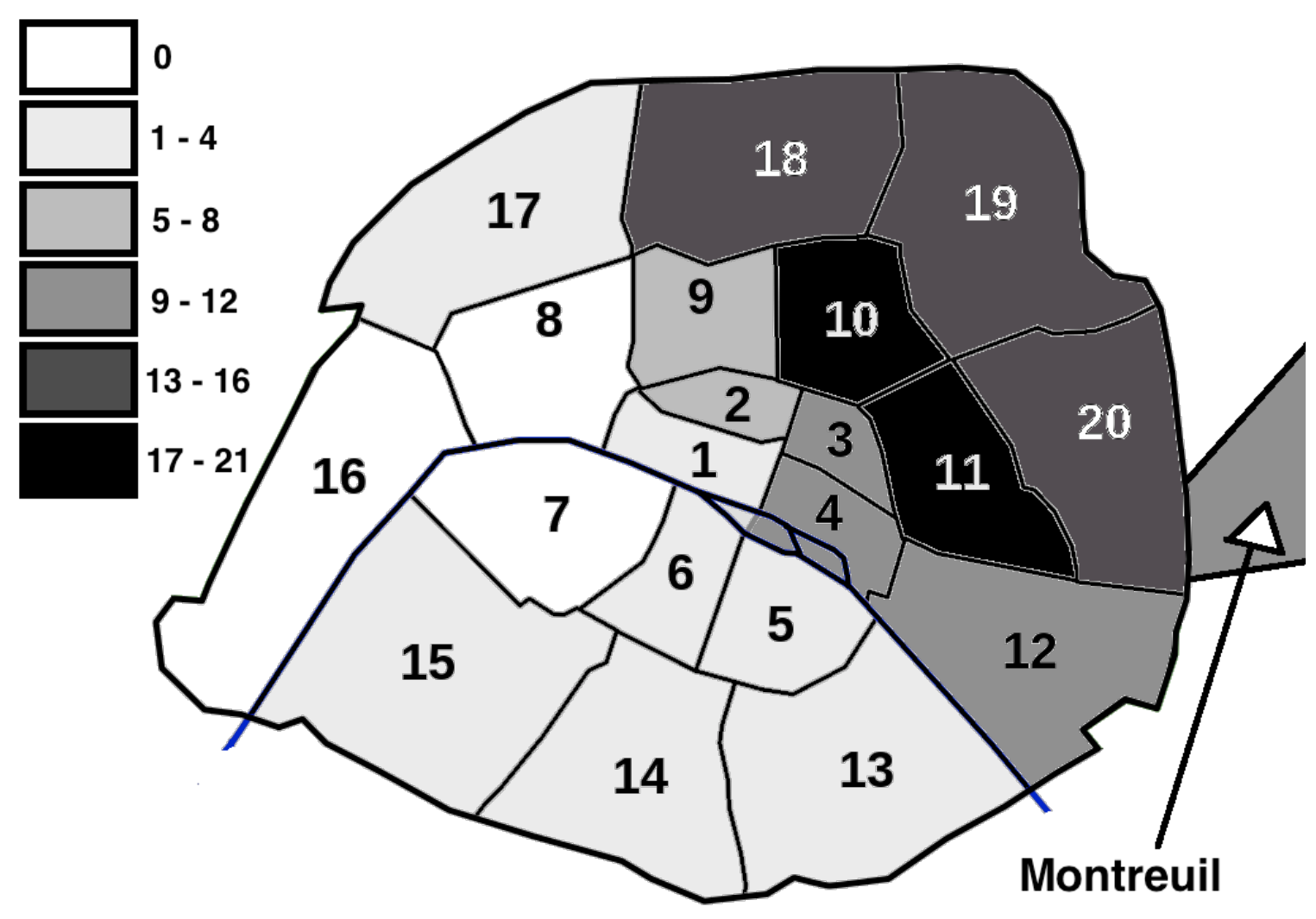

Source: The original map image was created by Thomas Steiner for Wikimedia Commons and is free of copyright restrictions, http://commons.wikimedia.org/wiki/File\%3AParis-map-arr.svg.

It is clear that the rise of the bobo is inextricably linked to the rapid gentrification of northeastern Paris in the early 2000s. Several factors converged to make this happen. First, property values in Paris began to increase dramatically at the end of the 1990s, so that between 1998 and 2012, the average price per square meter for an apartment in Paris rose $370 \% .{ }^{17}$ An increasing number of Parisians thus could no longer afford to live in the 
more expensive, traditionally bourgeois neighborhoods in the western part of the city and were obliged to consider moving eastward.

Second, the long-standing distinction between the bourgeois West and the proletarian East has eroded, while the distinction between Paris intra-muros and the banlieue has become increasingly important. As Anne Clerval points out in her study of the recent gentrification of Parisian neighborhoods, "[s]ince the formation of the banlieue rouge [i.e., the neighborhoods surrounding Paris with large working-class populations] in the interwar period and its reinforcement with the construction of public housing projects there in the 1960s, the socio-political opposition between Paris and the (working-class) banlieue has progressively supplanted the classic opposition between the West and the East of Paris in people's minds." 18 In recent decades, the growing number of immigrants, particularly from North Africa, in neighborhoods beyond Paris proper has only served to reinforce this distinction. As the traditional east/west divide has faded, so too has the social stigma associated with moving eastward.

Third and most importantly, a new form of cultural capital gradually emerged as the "social diversity" (mixité sociale) of these northeastern neighborhoods became increasingly valued, and living in a diverse neighborhood became a new form of social distinction. In her study of the gentrification of northeastern Paris, Anne Clerval explains: Because it is cosmopolitan and socially varied, the [gentrified] neighborhood does not represent a village, but a miniature world city, allowing the gentrifiers to link symbolically the nearby social diversity with their openness to the world. By doing this, the local space of the neighborhood becomes symbolic and material capital for the gentrifiers. It is part of a strategy of social distinction.... Valuing 
social diversity allows them above all to make a virtue out of necessity, transforming real estate limitations into deliberate choices. It is also an opportunity for conspicuous expression of high moral values, such as openness of mind and tolerance - both of which are close to the values of the cultivated grande bourgeoisie. ${ }^{19}$

Despite bobos' proximity to working-class populations, the effects of gentrification call into question the value or even the possibility of social mixing between the two populations, as Michel Pinçon and Monique Pinçon-Charlot point out in $\mathrm{La}$ violence des riches:

This urban imperialism paradoxically goes hand in hand with a display of the desire for social diversity. For example, the new inhabitants in the Goutte d'Or neighborhood [in northern Paris] voluntarily participate in local associations that bring welcome educational support to children of immigrants. But it is also true that these same people founded an association, Droit au calme, to protest against illegal nighttime activity in the neighborhood. Social mixing has its limits. ${ }^{20}$ The informants for this study agreed that there were limited possibilities for social mixing between bobos and members of the original communities. This is one of the indications they provided of the hypocrisy of being a bobo (in the next section on the definitions of bobos provided by the interviewees, we will see that many of them also mentioned the hypocrisy of bobo political views):

“They live near ordinary working-class folks, and they'll have a coffee in a café standing at the counter with people from the neighborhood, but while wearing cashmere. They don't actually ever become friends with these people." (Antoine) 
“[People might think I'm a bobo] but I'm not, because I don't make enough money, but also because bobos don't really mix with other people from the neighborhood, with non-bobos, but I mix.” (Sophie)

I noted earlier that the term "bobo" is almost always used pejoratively, and that few of the interviewees self-identified as bobos even though they thought others would identify them as such. To understand why this is the case, it is useful to think about how the term has been used, by whom, and to what ends. In their article "Beyond Identity," Rogers Brubaker and Frederick Cooper push us "to explain the processes and mechanisms through which [social categories] can crystallize, at certain moments, as a powerful compelling reality"- that is, to interrogate what work these categories are being asked to do in the social contexts in which they are used. ${ }^{21}$

The term "bobo" can be used pejoratively by both the original working-class inhabitants of a neighborhood (to expose the hypocrisy of bobos) and by the gentrifiers themselves (to deny that they are a part of that hypocritical population). In either case, use of the term serves to bring to light the symbolic violence committed against Boboland's original inhabitants through the bobos' hypocritical act of flaunting the social diversity of their neighborhood as cultural capital, while at the same time avoiding meaningful social interaction with the non-bobo population. Indeed, with descriptions like the one offered by geographer Christophe Guilluy, it is hardly surprising that few people would self-identity as bobo:

The sympathetic image of the 'bobo-explorer' arriving in the land of immigrants and the working class conceals the reality of a violent conquest of property. The euphemization of this process is emblematic of a capitalist libertarian [libéral- 
libertaire] time period where the predator often puts on a face of tolerance and empathy. ${ }^{22}$

\section{Bobo Culture}

The most fruitful parts of these interviews were the open-ended definitions of "bobo" that these informants provided, and it was surprising how similar their definitions were. For example, an element that everyone mentioned as part of the definition of bobo was their professional trajectories. Generally speaking, they all agreed that bobos tend to pursue professions in innovative, creative fields, especially in fashion, media, or technology.

"They have jobs in the 'knowledge economy,' in media, in dot-coms."

"They work in creative fields, in communication, new technologies."

(François)

"They're in advertising, architecture, cinema, fashion." (Sophie)

Every informant also included political views in their definition, whereby bobos are necessarily located on the Left, especially when it comes to environmental and social issues. As an expression of their political values, they tend to shop for organic foods and are attracted to products marketed as sustainable or fair-trade.

"[A bobo] identifies with politically left values; against racism, for same-sex marriage, and doesn't have a problem with paying taxes." (Nicole)

Yet, as the quotes below illustrate, politics is another area that highlights the perceived hypocrisy of bobos:

"[A bobo is someone who] eats organic food, who tries to be environmentally 
responsible; someone who rides a bike, but who will nevertheless take a plane to go to Thailand." (Benoit)

"A big part of being a bobo is eating organic food and paying attention to the environment, but only to a point; after all, bobos also need to pay attention to their level of comfort, to the well-being of their children.” (Hélène)

"People who make a decent living, politically on the Left, but who are a little uptight — they're not easygoing." (Xavier)

Every informant also mentioned age as an additional criterion. Once age was mentioned, I would ask for an age range; the average minimum age given was 31.7 years (ranging from 25 to 45), with the average maximum age as 47.2 years (ranging from 40 to 55).

Race and sexual orientation were less important criteria for the definition of bobos than geography, profession, age, and political views. Only one person brought up the issue of race, while sexual orientation was included in the definition of bobo in roughly one-third of the discussions (seven out of twenty-four). For the majority (five out of seven), gay people could not be bobos. It was not sexual orientation itself that prevented them from being bobos, but the fact that interviewees imagined gay people as less likely to form traditional families. One informant mentioned sexual orientation but did not think it mattered, and one thought gay men but not lesbians could be bobos, because of stereotypes of the consumption patterns of lesbians, stemming primarily from the antifashion stance articulated by second-wave-feminist lesbians. ${ }^{23}$

"Bobos are necessarily white. They can be gay, although the only gay bobos I know are men. I don't know any lesbian bobos, which is funny, because I always 
imagine them in couples." (Thomas)

"Their objectives are to start a family, to have children. I'm not a bobo, because gays can't be bobos. They're necessarily straight. They're in couples with one or two children." (Xavier)

"I don't know if you can be gay and a bobo. As for me, when I think of a bobo, I see someone who is straight, in a couple with children." (Agathe) “As for gay bobos, I'd say no, because [bobos] are in traditional families, with children.” (Julien)

Having children was viewed as another essential ingredient for being a bobo. Many respondents connected this particular element to the bourgeois part of the term. Children should not just be had, but should also be raised in a tranquil environment with plenty of cultural experiences. The hope of transferring cultural capital was of the utmost concern, as it would be for any bourgeois family. In her study of the French bourgeoisie, Béatrix Le Wita explains that "the distinguishing feature of the bourgeois would thus be to stress or at least not to leave to chance the need for the heir actively to take possession of the values of the group." 24

"Bobos need to have children. They're bourgeois, and a bourgeois needs to make kids. It's a little suspicious if they don't, in which case they'd just be cool people (des branchés), but that's another category.” (Etienne)

"There's a strong anchoring to the model of the traditional family. Their families have been anchored to tradition for generations, but [bobos] are also rebelling against ancestral values, so there's this constant tension between innovation and tradition." (Thomas) 
In talking about leisure activities, many mentioned travel. For bobos, travel should not be too expensive and, in order to distinguish themselves from others, it should generally be off the beaten path. Ideally, it would involve the acquisition of cultural capital through encounters with "exotic" places. Visiting the family's country home, a common and relatively inexpensive practice among bourgeois families in France, offers another form of acceptable travel.

“Bobos love low-cost airlines, they're the 'Easy Jet' generation. That's what makes us bohemians; we travel." (Etienne)

"A big part of bobo-ness (boboïtude) is being eco-friendly, even for vacations. So you have a tendency to choose back-to-basics destinations; whether it's the budget or deluxe version, you want the real experience, not just halfway, but the real thing." (Christophe)

"Morocco, New York, London, San Francisco, I imagine mostly in a city, or else some kind of adventure destination (les terres d'av)." (Pauline) "Maybe in the country house in Normandy that they inherited?" (Sophie) “They don't do package vacations. [They'll stay] with friends in a big house in the country, or maybe a month of walking in the desert." (Elizabeth) Every interviewee mentioned the way that bobos dress as a criterion in their definitions. Generally speaking, bobos avoid well-known luxury brands and opt instead for less commonly known designers. They aim for a style that gives a superficial impression that they do not care too much about fashion, despite the amount of thought and sometimes money they invest in their looks.

"As for clothing, their easy-going look is deceptive, no big-name brands, but even 
so, they wear dresses that cost 200 euros.” (Sophie)

'I'd make a distinction between the 'grands-bobos' from the 'grande-boboïtude' on Avenue Montaigne, who wear clothes from Zadig et Voltaire, and the 'petitsbobos,' who try to achieve the same look for less." (Anne)

"A bobo does not oppose tradition, nor bourgeois values, but he needs to find ways to remix things, by recycling things from vintage clothing stores for example.” (Nicole)

"Mostly expensive brands, all in good taste and good quality, with a little H\&M mixed in from time to time." (Brigitte)

Economic resources are not sufficient, however, to dress like a bobo; a significant accumulation of knowledge of distinctive tastes is also necessary to recognize what is and what is not in "good taste." The expression of bobo taste is discreet in all forms of consumption, but this is particularly true with fashion, where codes are often decipherable only to other bobos. Moreover, navigation of this complex system of codes must appear effortless. These descriptions are very similar to the ways in which Le Wita defines the tastes of the bourgeoisie, whose "luxury has to be experienced and displayed modestly. Otherwise one runs the risk of being bracketed with that dreadful species, the upstarts (les parvenus)." 25 She adds that "their mastery of the art of detail that will distinguish them is presented as second nature," as "behaviours that really do 'go without saying.,$" 26$

“[In order to be a bobo,] you have to pay attention to every detail, while acting as if you don't care. I'm not sure how to say it. You're dressed very well, but pretending as if you didn't even try. I just happen to be dressed like this, you see, 
it's natural. You can't look like you pay attention to it. So you have to show some distance from that kind of thing, yet everything is studied, because even if you bought a pair of glasses from such-and-such store, you want people to think that you did it without thinking too much about it. You see, the antithesis of the bobo is somebody who gets dressed up in fancy clothes to go to the opera. But a bobo, no, he would think that's cheesy. He'll go to the opera with jeans, because you're certainly not going to act like you need to get dressed up to go to the opera." (Hélène)

“A friend of mine said that bobos didn't seem to care much about what they wear. I said no, that's totally wrong, because they do. It's studied. It is completely, completely studied from A to Z, from the amount of times you wash your hairyou want to have that little-bit-greasy effect, but not too much, so you're still clean. I mean, everything is very subtle. This is true for the bourgeoisie too, but [bobos] tend to take it to another level, I think." (Rachel)

In the end, the first criteria listed above (i.e., politics and profession) were less helpful than the other criteria, including family situations and tastes in travel and fashion, in helping me to understand why the term bobo has been more prominent in France than in the United States. With the latter criteria, it became clear that the bourgeois part of the definition of bobo, along with accompanying notions of social distinction and cultural capital, were of primary importance in answering the central question of this essay.

\section{Why the Term was more Successful in France than in the US (and why Bobos cannot be Dentists)}


"A bobo cannot be a dentist." (Etienne)

What reasons do these interviews provide for the relative success of the term bobo in France compared to the US? First, it should be noted that the interviewees used the two components of the term bobo--bourgeois and bohemian--frequently, and with ease in their descriptions. These terms come to the English-speaking world from French, of course, and one could imagine that the two ingredients might be more easily understood in the French context, and, hence, that the resulting portmanteau would also be more easily grasped and consequently more likely to catch on in France. Another possible explanation suggested by the part of the interviews about precursors to bobos is that, in France, there were people in the past who would be called bobos today, though there might not have been a name for them at the time. This may have allowed French people to grasp the sense of the word bobo with less effort than their American counterparts when it was first coined in 2000 .

Both of these factors may have facilitated the word's prominence in France relative to the United States, but in the sections below I argue that the most salient reasons offered by the interviews for why the term has had more influence in France than in the United States are: (1) in the interviewees' open-ended definitions, of the two components of the term bobo, the bourgeois part matters much more than the bohemian part; and (2) the bourgeois part of the definition is less suited to the US context than it is to the French context. For one thing, the notion of bourgeois assumes a society with clear notions of social class, where people believe that one does not ascend in status merely through hard work or merit, but rather one inherits membership in a social class from one's family via transmission of patrimoine and savoir-faire, a belief more commonly 
held in France than in the United States. For another, the acquisition of "cultural capital" is an essential ingredient for inclusion in the bourgeoisie, and references to "cultural capital" tend to be more readily discussed and understood in France than in the United States.

\section{Bobos are a Sub-category of the Bourgeoisie, a Category that is more Readily Understood in France than in the US}

David Brooks pointed out during my interview that, in representations of bobos since 2001, "the bohemian side has weakened and has gotten diluted, becoming a thinner and thinner patina on the regular old bourgeois." ${ }^{.7}$ Indeed, in all the interviews I conducted in Paris, people spent much more time discussing the bourgeois component of the definition than the bohemian part. As the following quotes indicate, for some interviewees the difference between bobos and the bourgeoisie was rather insignificant. In fact, bobos might simply be considered the latest incarnation of the bourgeoisie or as a sub-category of the larger category of bourgeois.

"Bobos are bourgeois in the sense that they want to live in comfort, have large families. The thing that makes them different is that they don't live in neighborhoods classified as bourgeois.” (Pauline)

"For me, I experienced the arrival of the term bobo merely as the birth of a new bourgeoisie." (Christophe)

"A bourgeois and a bobo are almost the same thing, they just dress differently [laughs].... A bourgeois is very attached to his family's wealth (patrimoine) and, well, so are bobos." (Agathe) 
If the bobo is simply a sub-species of bourgeois, to the extent that bourgeoisrelies on the notion that social class is passed from one generation to the next and runs counter to narratives of social mobility, bobo seems to have been destined to have more success in a society like France. In the United States, explicit references to class difference tend to be less common or less acceptable than in France, where awareness of class difference is widespread and readily discussed (this may be changing some with the arrival of "occupy" movements, references to the ninety-nine percent, and the success of Thomas Piketty's surprise best-seller on capital) ${ }^{28}$ An indication of the class taboo in the US is the deeply held, essentially American notion of the "self-made man." The French, who generally try to come up with French equivalents for American words that infiltrate the language, have yet to do so with this term, opting instead to use the expression le self made man, thereby preserving its Americanness. In France, belief that the class into which one is born functions as a determining factor for one's future social position is more common than in the US (though, oddly enough, studies seem to indicate that, if anything, there is slightly less social mobility in the US than in France).${ }^{29}$ Clearly, if class difference is a more legitimate, less taboo notion in France than in the US, then a term like bobo, which relies on the explicit class designator "bourgeois," will resonate differently in the two contexts. This is also why a term like "yuppie," whose definition relies almost entirely on economic capital (regardless of how that capital was obtained), resonates better in the United States, where there is a belief in social mobility. A term like bourgeois, whose definition assumes that class membership is inherited, does not register as well.

Pierre Bourdieu's understanding of the bourgeoisie, which is reflected in the 
interviewees' discussions, relies on a "a multidimensional status game in which people draw on three different types of resources [what he terms economic, cultural, and social capital] to compete for status [what he terms 'symbolic capital']. Distinct from economic capital (financial resources) and social capital (relationships, organizational affiliations, networks), cultural capital consists of a set of socially rare and distinctive tastes, skills, knowledge, and practices. ${ }^{\prime 30}$ The interviewees in my sample made it clear that economic capital was not sufficient to be bourgeois (and hence to be a bobo); this was particularly true with the descriptions of bobo tastes in fashion and travel. Rather, as the following quotes illustrate, to be a bobo requires the familial transmission of a sophisticated understanding of the rules of social distinction and of cultural capital.

"You don't necessarily need to have a lot of money to be a bobo. It's a question of aspirations, the pursuit of a certain lifestyle." (Nicole)

“But earning money isn’t enough. You need a certain lifestyle, certain tastes. Yet, at the same time, I'd probably say I'm not a bobo, because I don't earn 5,000 euros per month [laughs]." (Genevieve)

"You have to come from a bourgeois family to be a bobo." (Gabrielle) "You need a certain level of purchasing power, but they don't all come from a rich background.... Proper upbringing, which is translated from one generation to the next along with the notion of discretion, is what bobos share with the bourgeoisie." (Sabine)

In the last few years, two sociological studies of bobos have appeared, whose definitions also indicate that economic capital is not sufficient, much in the same way that it would not be sufficient for being bourgeois. The first, Paris bourgeois, Paris 
bohème (2013) explains that bobos form "a social group that occupies a relatively high position in the social hierarchy, endowed with some economic capital, although this can vary, along with strong social and cultural capital linked to family origin, educational pursuits and professional activities." ${ }^{\prime 1}$ The second, La République bobo (2014) defines bobos as "people whose cultural capital (high) carries more weight than their economic capital (varied) in determining where to live and which values they consider positive or negative." 32

What stood out in the interviews was the extent to which respondents made more or less explicit references to Bourdieusian notions of social distinction and taste, with many actually using the words "distinguish" or "distinction" in their descriptions:

"A bobo is constantly haunted by the issue of how to distinguish himself from others. The enemy of the bobo is your regular Joe (le beauf)." (Etienne) “They wouldn't take the same trips as everyone else; they need to distinguish themselves. They wouldn't go to Club Med, for example.” (Anne) "Either going to the family's country house or doing something more adventurous. Whichever they choose, it must be complicated for them, since they can't just do things simply. I imagine that they don't go to Dubai, that's no place for bobos. Maybe they simply go to Brittany?" (Thomas) "For bobos, consumption of goods is always recherché." (François) "You need to be conventional while at the same time distinguishing yourself, in clothing, but also in cuisine." (Thomas)

"Bobos tend to avoid risk, but at the same time they need to distinguish themselves from others in their consumption of goods." (Anne) 
"There's a part of the bourgeois conception that to become an adult [you need] dance lessons, museums, all kinds of sports which can contribute to social distinction, so maybe not soccer." (Thomas)

Some American sociologists have argued that the Bourdieusian notion of cultural capital does not fit the US context nearly as well as it does the French. ${ }^{33}$ In his study of American consumption patterns, Douglas Holt explains that "influential recent studies have challenged [Bourdieu's theory's] usefulness for explaining how social reproduction works in the contemporary United States. ${ }^{\prime 34}$ Similarly, Michèle Lamont, in her comparative study of upper-middle-class values in France and the US, argues that "American upper-middle-class members stress socio-economic and moral boundaries more than they do cultural boundaries; this is not the case in France." ${ }^{35}$ In a study coauthored by Lamont and Annette Lareau, they account for these differences in the following way:

Important features of American society, such as high social and geographical mobility, strong cultural regionalism, ethnic and racial diversity, political decentralization and relatively weak high culture traditions suggest that culture is not as highly class-differentiated in the US as it is in France. Indeed, American research suggests that class cultures are weakly defined in the US; that ethnic and racial minorities reinterpret mainstream culture into their own original; that high culture is being debased by commercialization; that the highly educated consume mass culture, but also have a wider range of cultural preferences which distinguishes them from other groups. ${ }^{36}$ In the end, the relative prominence of the term bobo in France is not surprising, 
given that the bourgeois part of the definition is more important than the bohemian part, that the concept of bourgeois is more readily understood in France, and the inaptness of Bourdieusian notions of cultural capital in the United States (and their centrality to the definition of bobo). The opening quote to this section from Etienne- that bobos cannot be dentists - might be less readily understood in the American context. While being a dentist might provide enough economic capital to be a yuppie in the US, Etienne imagines, it would not provide enough cultural capital to be a bobo in France. 


\section{Appendix 1}

Age, sex and profession of informants

\begin{tabular}{|c|c|c|c|}
\hline Alias & Sex & Age & Profession \\
\hline Etienne & Male & 42 & Psychology \\
\hline Sabine & Female & 42 & Cinema \\
\hline Virginie & Female & 45 & Education \\
\hline André & Male & 47 & Entertainment \\
\hline Didier & Male & 49 & Marketing \\
\hline Sylvie & Female & 40 & Travel \\
\hline Sophie & Female & 45 & Cinema \\
\hline Nicole & Female & 46 & Advertising \\
\hline Marie & Female & 42 & Internet services \\
\hline Benoît & Male & 46 & Marketing \\
\hline Louis & Male & 45 & Marketing \\
\hline Geneviève & Female & 42 & Cinema \\
\hline Hélène & Female & 38 & Psychology \\
\hline François & Male & 43 & Radio \\
\hline Elisabeth & Female & 49 & Music performance \\
\hline Gabrielle & Female & 47 & Cinema \\
\hline Julien & Male & 45 & Publishing \\
\hline Xavier & Male & 48 & Music performance \\
\hline Thomas & Male & 33 & Academe \\
\hline Rachel & Female & 41 & Curating \\
\hline
\end{tabular}




\begin{tabular}{|l|l|l|l|}
\hline Anne & Female & 38 & Fashion \\
\hline Brigitte & Female & 47 & Real estate \\
\hline Agathe & Female & 39 & Cinema \\
\hline Sébastien & Male & 46 & Entrepreneur \\
\hline
\end{tabular}

${ }^{1}$ David Brooks, Bobos in Paradise: The New Upper Class and How They Got There (New York: Simon \& Schuster, 2001).

${ }^{2}$ Telephone interview with David Brooks, 22 March 2013.

${ }^{3}$ Brooks, Bobos in Paradise, 42.

${ }^{4}$ These numbers come from searches done with Lexis-Nexis for each year from 2000 through 2013. For the French data line, I used the search terms "bobo AND bourgeois AND bohème" (this was necessary, because searching with the term "bobo" on its own produced many unwanted results, especially since "bobo" is the word French children use for a small wound, like "boo-boo" in English), with the filter for high similarity on (this prevents nearly identical articles from being counted more than once), in the Lexis-Nexis database "all French news." For the US data line, I used the search terms "bobo AND bourgeois AND bohemian" (to mirror the French search), with the filter for high similarity on, in the Lexis-Nexis database "all English news, country=United States." ${ }^{5}$ These numbers come from searches done with Lexis-Nexis for each year from 2000 through 2013. I used the search terms "bobo AND bourgeois AND bohème" (this was necessary, because searching with the term "bobo" on its own produced many unwanted 
results, especially since "bobo" is a term that French children use as a synonym for "wound)" and the search terms "(Amérique OR Etats-unis OR américain OR américaine OR américains OR américaines OR “New York” OR new-yorkais OR new-yorkaise OR new-yorkaises), with the filter for high similarity on, in the Lexis-Nexis database "all French news." I would like to thank Victor Varenne for his help with the initial stages of this part of the project.

${ }^{6}$ These numbers come from searches done with Lexis-Nexis for each year from 2000 through 2013. I used the search terms "bobo AND bourgeois AND bohemian" (to mirror the French search) and the search terms "Paris OR Parisian OR French OR France" with the filter for high similarity on, in the Lexis-Nexis database "all English news, country=United States."

${ }^{7}$ Philippe Dupuy and Charles Berberian, Bienvenue à Boboland (Paris: Éditions Audie, 2008).

${ }^{8}$ Philippe Dupuy and Charles Berberian, Global Boboland (Paris: Fluide Glacial, 2009).

${ }^{9}$ Benoît Daragon and Bixente Barnetche, Bobos de merde (Paris: Éditions Privé, 2011), 17. This and all other translations from French to English are the author's own.

${ }^{10}$ Géraldine de Margerie, Le Dictionnaire du look (Paris: Robert Lafont, 2011), 59.

11 This is similar to Sarah Maza's argument in The Myth of the French Bourgeoisie that the "bourgeois was almost invariably what someone else was." Sarah Maza, The Myth of the French Bourgeoisie (Cambridge: Harvard University Press, 2005), 5.

${ }^{12}$ Many parallels can be drawn between the gentrification of the 14th arrondissement in the late 1970 s/early 1980 s and the gentrification of northeastern Paris in the early 2000 s. In Sabine Chalvon-Demersay's Le Triangle du XIVe: Des nouveaux habitants dans un 
vieux quartier de Paris (Paris: Éditions de la Maison des sciences de l'homme, 1984), she points out how the newcomers have limited interaction with the original population of the neighborhood, how they appreciate the "authenticity" of their new neighborhood, and how they tend to eschew conspicuous consumption in their new homes. The gentrification of northeastern Paris by bobos shares all of these features. 13 "Baba cool" can be roughly translated into English as "hippie," except that it is perhaps less tied to the specific time period of the 1960s or 70s.

${ }^{14}$ See for example, “Le 'hipster,' un bobo version 'US'?” Marianne 808, 13 October 2012; Vahram Muratyan, Paris versus New York: A Tally of Two Cities, "La barbe," (New York: Penguin, 2011); or this image from the book's website: http://parisvsnyc.blogspot.com/2010/11/la-barbe.html 15 Jean-Michel Helvig, “'Bobos' à gogo pour la gauche parisienne,” Libération, 23 March 2001, http://www.liberation.fr/cahier-special/2001/03/23/bobos-a-gogo-pour-la-gaucheparisienne_358866.

${ }^{16}$ No interviewees mentioned the $7^{\text {th }}, 8^{\text {th }}, 15^{\text {th }}$ or $16^{\text {th }}$ arrondissements; one to four interviewees mentioned the $1^{\text {st }}, 5^{\text {th }}, 6^{\text {th }}, 13^{\text {th }}$, or $14^{\text {th }}$ arrondissements; five to eight interviewees mentioned the $2^{\text {nd }}$ or $9^{\text {th }}$ arrondissements; nine to twelve interviewees mentioned Montreuil or the $3^{\text {rd }}, 4^{\text {th }}$, or $12^{\text {th }}$ arrondissements; thirteen to sixteen interviewees mentioned the $18^{\text {th }}, 19^{\text {th }}$ or $20^{\text {th }}$ arrondissements, and seventeen to twenty-one interviewees mentioned the $10^{\text {th }}$ or $11^{\text {th }}$ arrondissements.

${ }^{17}$ Anne Clerval, Paris sans le peuple: La gentrification de la capitale (Paris: La découverte, 2013), 58.

18 Ibid., 149. 
${ }^{19}$ Ibid., 168-70. In her study of the gentrification of Boston's South End, Sylvie Tissot describes a similar process: "The residential project that [the gentrifiers] carried forth, at some remove from a certain style of upper-middle-class life, rapidly transformed into a moral quest. The ethic uniting these 'good neighbors' involves a stigmatization of the closed, in-group mentality of the residential suburbs, replaced by ... a rejection of racial segregation and celebration of multiculturalism that has not, however, eliminated the still-powerful fear of the black population and its culture.... The watch-word 'diversity' - implying that 'others' be recognized, but in restricted places and numbers ...-allowed for a tight control of coexistence, though this coexistence was nevertheless strongly valorized.” Sylvie Tissot, Good Neighbors: Gentrifying diversity in Boston's South End, trans. David Broder and Catherine Romatowski (New York: Verso, 2015), $257-59$.

${ }^{20}$ Michel Pinçon and Monique Pinçon-Charlot, La Violence des riches: Chronique d'une immense casse sociale (Paris: La Découverte, 2013), 207-209.

${ }^{21}$ Rogers Brubaker and Frederick Cooper, "Beyond 'identity,"” Theory and Society 29 (2000), 5 .

${ }^{22}$ Christophe Guilluy, Fractures françaises (Paris: François Bourin, 2010), 93, cited in Pinçon and Pinçon-Charlot, La Violence des riches, 207.

${ }^{23}$ For an analysis of the effect of the anti-fashion stance of second-wave feminists on stereotypes of the consumption patterns of lesbians, see Danae Clark, "Commodity Lesbianism," in The Lesbian and Gay Studies Reader, ed. Henry Abelove, Michèle Aina Berale, and David M. Halperin (New York: Routledge, 1993), 186-201.

${ }^{24}$ Béatrix Le Wita, French Bourgeois Culture, trans. J. A. Underwood (Cambridge: 
Cambridge University Press, 1994), 5.

25 Ibid., 57.

26 Ibid., 67.

27 Telephone interview with David Brooks, 22 March 2013.

${ }^{28}$ See for example, Gregory Mantsios, "Class in America: Myths and Realities," in Race, Class and Gender in the United States, ed. Paula S. Rothenberg (New York: St Martin's Press, 1995); David L. Weakliem and Anthony F. Heath, “The Secret Life of Class Voting: Britain, France, and the United States since the 1930s," in The End of Class Politics: Class Voting in a Comparative Context, ed. Geoffrey Evans (Oxford: Oxford University Press, 1999); and Arthur Marwick, Class: Image and Reality in Britain, France and the USA since 1930 (New York: Oxford University Press, 1980).

${ }^{29}$ See for example, Miles Corak, "Income Inequality, Equality of Opportunity, and Intergenerational Mobility," Journal of Economic Perspectives 27, 3 (2013): 79-102; and Arnaud Lefranc and Alain Trannoy, "Intergenerational Earnings Mobility in France: Is France more Mobile than the US?" Annales d'économie et de statistique 78, 2 (2005): $57-77$.

${ }^{30}$ Douglas B. Holt, “Does Cultural Capital Structure American Consumption?” The Journal of Consumer Research 25, 1 (1998), 3.

${ }^{31}$ Sophie Corbillé, Paris bourgeois, Paris bohème: La ruée vers l'Est (Paris: Presses universitaires de France, 2013), 96 (emphasis added).

${ }^{32}$ Laure Watrin and Thomas Legrand, La République bobo (Paris: Éditions Stock, 2014), 33 (emphasis added).

${ }^{33}$ See for example Bonnie Erikson, "Culture, Class, and Connections," American Journal 
of Sociology 102,1 (1996): 217-51; David Gartman, “Culture as Class Socialization or Mass Reification: A Critique of Bourdieu's Distinction,” American Journal of Sociology 97 (September 1991): 421-47; John R. Hall, “The Capital(s) of Cultures: A Nonholistic Approach to Status Situations, Class, Gender, and Ethnicity," in Cultivating Differences: Symbolic Boundaries and the Making of Inequality, ed. Michèle Lamont and Marcel Fournier (Chicago: University of Chicago Press, 1992), 257-85; David Halle, Inside Culture: Art and Class in the American Home (Chicago: University of Chicago Press, 1993).

${ }^{34}$ Holt, "Does Cultural Capital Structure," 5.

${ }^{35}$ Michèle Lamont, Money, Morals, and Manners: The Culture of the French and American Upper-Middle Class (Chicago: University of Chicago Press, 1992), 5.

${ }^{36}$ Michèle Lamont and Annette Lareau, "Cultural Capital: Allusions, Gaps, and Glissandos in Recent Theoretical Developments," Sociological Theory 6 (1988), 161. The "American research" referred to in this quotation includes: James A. Davis, “Achievement Variables and Class Cultures: Family, Schooling, Job and Forty-Nine Dependent Variables in the Cumulative G.S.S.” American Sociological Review 47 (1982): 569-86; Ruth Horowitz, Honor and the American Dream: Culture and Identity in a Chicano Community (New Brunswick: Rutgers University Press, 1983); Elliot Liebow, Tally's Corner (Boston: Little Brown, 1967); Joseph Horowitz, Understanding Toscanini: How He Became an American Culture-God and Helped Create a New Audience for Old Music (Minneapolis: University of Minneapolis Press, 1987); Paul DiMaggio, "Classification in the Arts," American Sociological Review 52 (1987): 44055; Paul DiMaggio and John Mohr, "Cultural Capital, Educational Attainment, and 
Marital Selection," American Journal of Sociology 90 (1985): 1231-61; Michael Hughes and Richard A. Peterson, "Isolating Culture Choice Patterns in the US Population," American Behavioral Scientist 26 (1983): 459-78; and Robert V. Robinson and Maurice A. Garnier, "Class Reproduction among Men and Women in France: Reproduction Theory on its Home Ground," American Journal of Sociology 91 (1985): 250-80. 